\title{
Gone and forgotten: where has the "literature" gone?
}

\author{
David F. Albertini
}

Published online: 25 April 2012

(C) Springer Science+Business Media, LLC 2012

To anyone engaged in the training of the next generation of basic and clinical scientists, urging students to gain "command of the literature" has become somewhat of an exercise in frustration. Consider for a moment taking heed to a mentor's encouragement a mere 40 years ago, when libraries were occupied by willing, able and capable young minds, hell-bent on devouring articles from a manageable collection of journals relevant to the field of research upon which their original work would be based. Many small coins and a copying machine at hand were all that would be needed to collect, process, and gain command of the scholarly literature. Some will recall the days of reprint requests through snail mail as a worthwhile and profitable means to attain the same goal-collecting reprints of articles that would, in fact, be assimilated into the scholarly mindset. Fast forward to the computer age - the dizzying pace in proliferation of journals and articles now renders the contemporary student with immediate access to many thousands of key-word driven compilations that, at a finger stroke, bring a recent paper into the visual field of those willing, able, and capable young minds. But at what cost?

While the limits of attention to detail are arguably finite, even a well honed reductionist in today's biomedical enterprise remains likely to have missed a beat or a "big picture" while sifting through what must be acknowledged as voluminous data bases, orders of magnitude greater than what was available 40 years ago. PubMed searches from nearly

Capsule Gaining command of the literature for the next generation of specialists in reproductive medicine is threatened by the digital age and the growing tendency to overlook classic papers from the past.

D. F. Albertini $(\bowtie)$

University of Kansas Medical Center,

Kansas City, KS 66103, USA

e-mail: dalbertini@kumc.edu anywhere now can bring a student into immediate contact with the recent literature, depending on what you call recent. As your editor, it may come as a surprise that not a manuscript goes through the JARG system without paying attention to the appropriateness of citations that form the underpinnings of what we all hope will become a new and exciting advance in the field of reproductive medicine. And, as many of you know when providing reviews on these manuscripts, the growing tendency to base citations on the rearward, and sometimes arbitrary, target of ten years often overlooks the many foundational contributions made by our forbears in reproductive medicine. Such is the maligned fate of many seminal findings that happened to have been published at a time that preceded PubMed. And such is the substance of "gone and forgotten" when it comes to setting expectations of the not-so-great variety, while guiding our students and trainees in the quest for "command of the literature." As memories fade away, so too do the foundations and cornerstones in our own discipline.

It is a duty and responsibility of mentors to impart to our students the discipline and motivation needed to keep pace with advances and contextualize the present wave of discovery in a historical light, when at all possible. Easier said than done, but well worth it all the while. Many within the establishment of reproductive medicine - clinicians and/or scientists alike - have benefitted from alliances with leaders of the field who link the present to the past in forming lineages that not surprisingly sound like a history of assisted reproductive technology - the Jones, the Edwards, the Mastroiannis - and on it goes. And nothing captures the attention of students better than a good story.

Here our fearless leader and storyteller par excellence through much of the recent evolution of ARTs has been none other than Howard Jones himself.

While Howard and his late wife, Georgeanna, carved the path to implementing IVF in the US, following the footsteps 
of Bob Edwards and taking reproductive endocrinology to new heights, the storytelling runs deep and the historical context rich with implications, thanks to author Rebecca Skloot. Our cover this month recognizes the birth of HeLa cells and the revelations Skloot provides us with in her engaging and powerful account of the story behind Henrietta Lacks (The Immortal Life of Henrietta Lacks, Crown Publishers, New York, NY, ISBN 978-1-40005217-2). Skloot sets a new standard for those interested in the public perception of science and medical research. Embracing this topic with investigative acumen and objectivity, Skloot attains a level of insight rarely captured by journalists or historians committed to balancing the truth behind scientific breakthroughs and their impact on patient care. In the end, the matter of using cells taken from a patient under the care of a young Dr. Howard Jones becomes a sentinel of things to come in the field of human ARTs.

The parallels between a forgotten donor and literature that has suffered the fate of institutional memory are uncanny. But to bring the subject of HeLa cells into perspective requires more than a casual discussion of the roots of human ARTs and the immortalization of pioneers in reproductive medicine. It remains for all involved with mentoring the next generation of clinician and basic scientists to follow the practices of leaders like Dr. Jones. By his example, and that of the many leaders we have been privileged to work with, gaining command of the literature in our field will be forever etched in the next generation of reproductive scientists and practitioners. Happy Birthday, Howard, and thanks for the memories! 